\title{
Effect of Project-Based Learning through blogging on EFL students' writing ability
}

\author{
Ikrima Halimatus Sa'diyah ${ }^{1}$, Bambang Yudi Cahyono ${ }^{2}$ \\ ${ }^{1}$ Graduate Program in English Language Teaching, Universitas Negeri Malang, Indonesia \\ ${ }^{2}$ English Department, Faculty of Letters, Universitas Negeri Malang, Indonesia \\ 1 ikrimahalimatus12@gmail.com (corresponding author) \\ ${ }^{2}$ bambang.yudi.fs@um.ac.id
}

Received: May 30, 2019; Accepted: September 27, 2019;

Published: September 30, 2019

\begin{abstract}
This study scrutinized how Project-Based Learning (PjBL) through blogging affects the writing ability of EFL students across self-efficacy levels. A quasiexperimental design was applied and it was conducted in nine sessions. It involved forty-one students of the English Department of a state university in East Java, Indonesia who attended the argumentative writing class. PjBL through blogging was conducted on the experimental group, while the conventional method was conducted on the control group. The data were collected from writing tests and self-efficacy questionnaires. Independent sample t-test was used in analyzing the students' scores. The finding disclosed that the students utilizing PjBL through blogging got better scores in writing than the ones using the conventional method. It was also revealed that students having high self-efficacy and those having low self-efficacy taught using PjBL through blogging had no significant difference in writing ability.

Keywords: EFL students; Project-Based Learning (PjBL); blogging; writing ability; self-efficacy

How to cite this paper (in APA style): Sa'diyah, I. H., \& Cahyono, B. Y. (2019). Effect of Project-Based Learning through Blogging on EFL students' writing ability. Journal on English as a Foreign Language, 9(2), 199-216. doi:http://dx.doi.org/10.23971/jefl.v9i2.1341
\end{abstract}


DOI: http://dx.doi.org/10.23971/jefl.v9i2.1341

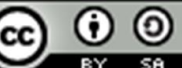

One of the language skills that must be acquired by students of English as a foreign language (EFL) is writing skill. Writing is considered as a productive skill and activities in writing lead to written products in the process of EFL learning. This is in line with what Cahyono and Widiati (2006) stated that anything dealing with writing is categorized as products of written texts such as handwritten drafts, prints, and digitalized documents. Besides, writing becomes a crucial skill in the tertiary level. This is affirmed by the fact that EFL students especially those in the undergraduate, graduate, and postgraduate levels are required to write the bachelor thesis, masters thesis, and dissertation, respectively. Sometimes, the students are required to write articles for publications in some scientific journals, such as those indexed by Scopus. Consequently, writing is considered to be the most demanding skill to be acquired by EFL students since it belongs to a complex process which requires skills from thinking about what to write to finish the written product (Cortazzi \& Jin, 1996).

Components of writing covering content, vocabulary items, organization, grammatical structure and mechanics (punctuation, spelling, capitalization, paragraphing) may become challenges for students. The students somehow tend to be timid during the process of writing since it is not easy for them to explore and organize ideas, or find appropriate words in writing. Besides, another challenge faced by the students in writing is derived from the differences of cultural backgrounds between the students' mother tongue, in this case, Indonesian and English. The students somehow strive to transfer meanings from Indonesian to English contexts to make their writing understandable if they are read by other people (Ariyanti, 2016). Hence, it is not easy to writing, particularly when students need to deal with generating, organizing or even translating ideas or thoughts into an understandable text (Richards \& Renandya, 2002).

To help EFL students face the challenges, an effective method in teaching writing is suggested to be applied to expand their ability in writing. One of the suggested methods of teaching writing is project-based learning (Thomas, 2000; Goodman, 2010) abbreviated as PjBL. The key characteristic of PjBL is a high level of authenticity. In PjBL, students' project needs to be accomplished by the students. The students need to utilize their previous knowledge and skills or a

Journal on English as a Foreign Language, 9(2), 199-216

Copyright (C) 2019 by JEFL, p-ISSN 2088-1657; e-ISSN 2502-6615 
combination of knowledge, skills, and aids that other people have developed in accomplishing their tasks. They can collect some information through books, online databases, videotapes, their own experience, or even interviews, and these depend on what information is needed by the students to assist their project.

Studies investigating the use of PjBL in writing have been conducted by scholars. The studies revealed that the students who utilize PjBL obtained better scores in writing than those who apply a conventional method (Thitivesa \& Essien, 2013; Sadeghi, Biniaz, \& Soleimani, 2016). Other studies indicated that the use of PjBL developed students' writing ability, boosted the students' creativity and enthusiasm as well as their problem-solving ability since it provides the students an opportunity to create products in an enjoyable atmosphere through the integration of their knowledge, attitude and skills in an authentic context (Eskrootchi \& Oskrochi, 2010; Papanikolaou \& Boubouka, 2010; Astawa, Artini, \& Nitiasih, 2017).

According to Stoller (2006) in Beckett and Miller (2006), PjBL comprises 6 stages as shown in Figure 1.

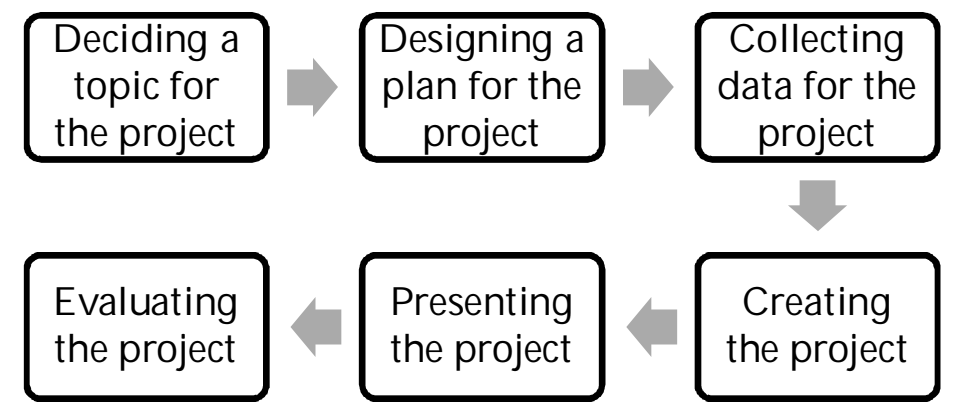

Figure 1. The stages of PjBL (Stoller, 2006)

The first stage is deciding a topic for the project. In this stage, the teacher and students discuss together the topic of the project. The second one is designing a plan for the project. The students think about what they will do to finish the project. Besides, the students are allowed to design their project. The third stage is collecting the data for the project. The students are required to collect, analyze and organize the data to solve problems or to accomplish the tasks given. Then, they are required to do the project by applying the knowledge they obtain through the process of inquiring. Creating the project 
becomes the upcoming stage in which students do the assigned project after they get the data to strengthen their tasks or projects. The fifth stage is presenting the project. In addition to accomplishing the task or the project, the students have to present the result of the project. They may use their communicative skill in presenting the result of the project. The aim of presenting the project is to have feedback from their classmates and their teacher for the betterment of their project result. Evaluating the project is the last stage in which the project is appraised by the teacher and the students. All six stages enable the students to be active thinkers and creative project doers.

Markham, Larmer, and Ravitz (2003) stated that one of the fundamental criteria of PjBL is using modern ICT tools; the present study utilizes an online platform in the form of a blog as a medium on applying PjBL. Campbell (2003) stated that blogs or weblogs are considered as online journals that enable users to update their words, ideas, and thoughts. The activities of the bloggers while they are writing or sharing their ideas on their blogs are called blogging.

Blogs are classified into three types and all of them are used in the classrooms (Campbell, 2003). The first is a tutor blog. It is produced by a tutor whose objective is stimulating students by giving texts written by people, particularly by native speakers, assisting web resources regarding lessons, and providing feedback or comments on the blog entries. The second type is the learner blog. As the term suggests a learner blog is owned by individual learners. It enables students to keep their online journals, particularly for writing practices. The last type is the class blog. It is considered as a collaborative product which allows students to post anything regarding lessons. Hence, the students should understand lessons in the classroom as the lessons are further hashed out and cleared up in the class blog. As the students are required to make their blogs, the learner blog becomes the focus of the study.

Based on the aforementioned explanation, the way PjBL through blogging affects students' writing ability perceived from self-efficacy levels was scrutinized. Self-efficacy is included as an additional variable in this research since in writing activities, students have their level of self-efficacy to perform a written task successfully, and especially how they get and organize ideas. Therefore, two research questions are composed, "Is there any significant difference in the writing ability of the students taught by using PjBL through blogging and those taught by using the conventional way?" and "is there any significant difference in the writing ability of the students who have high self- 
efficacy and those who have low self-efficacy taught by using PjBL through blogging?"

The results of the present study are expected to serve contribution both theoretically and practically. In conjunction with a theoretical contribution, it is expected that the result of this study strengthens the existing theory and the previous findings on the application of project-based learning on writing ability. For practical needs, before applying project-based learning through blogging, English teachers should make the students familiar with blogging. If some students are not familiar with blogging, the English teachers should give one meeting to explain about blogging. Additionally, they need to take into account the materials along with interesting topics and they should have adequate knowledge and understanding of the procedure of project-based learning, its application in the classroom. Furthermore, this study will provide additional insights for future researchers into the practice of using PjBL through blogging.

\section{METHOD}

This study applied a quasi-experimental design as it involved two intact groups of students without random selection. It also used a factorial design with two independent variables: active and attribute (Latief, 2012). The active variable was $\mathrm{PjBL}$ through blogging and the attribute variable was self-efficacy. There are two self-efficacy levels: high and low self-efficacy. The subjects of this study were fourth-semester EFL students who attended the argumentative writing course at the English department of a state university in East Java, Indonesia. There were nineteen students in the experimental group and twentyone students in the control group.

PjBL through blogging was applied to the experimental group. Stoller's (2006) six stages in PjBL were applied during the treatment. Meanwhile, the conventional method was applied to the control group. In the English department of the university, the students were conventionally taught using process writing which consisted of five stages: planning, drafting, editing, revising, and publishing. The treatment was implemented in 9 meetings including the pretest and posttest administration. Table 1 presents the schedule of the treatment. 
Table 1. The Schedule of the Treatment

\begin{tabular}{|c|c|c|}
\hline Meeting & Experimental group & Control group \\
\hline 1 & Administering the pretest & Administering the pretest \\
\hline 2 & $\begin{array}{l}\text { Pre-activity } \\
\text { - Explaining the characteristics of } \\
\text { opinion essay } \\
\text { - Asking the students to read and } \\
\text { discuss a model text: "The right } \\
\text { to Die" } \\
\text { - Introducing the students to } \\
\text { blogging } \\
\text { - Explaining an essay project } \\
\text { through blogging }\end{array}$ & $\begin{array}{l}\text { Pre-activity } \\
\text { - Explaining the } \\
\text { characteristics of opinion } \\
\text { essay } \\
\text { - Asking the students to } \\
\text { read and discuss a model } \\
\text { text: "The right to Die" }\end{array}$ \\
\hline 3 & $\begin{array}{l}\text { Deciding a topic and designing a } \\
\text { plan for the first project } \\
\text { - Deciding the topic "Laws } \\
\text { against cell phone use while } \\
\text { driving" } \\
\text { - Asking the students to make a } \\
\text { group of 3, plan their blog and } \\
\text { its template, and make an } \\
\text { outline }\end{array}$ & $\begin{array}{l}\text { Planning and Drafting } \\
\text { - Assigning a topic "Laws } \\
\text { against cell phone use } \\
\text { while driving" } \\
\text { - Asking the students to } \\
\text { brainstorm ideas, make an } \\
\text { outline, and write a rough } \\
\text { draft to be submitted for } \\
\text { feedback from classmates }\end{array}$ \\
\hline 4 & $\begin{array}{l}\text { Collecting the data for the project } \\
\text { - Asking the students to make } \\
\text { groups and collect data about }\end{array}$ & $\begin{array}{l}\text { Revising } \\
\text { - } \quad \text { Returning the students' } \\
\text { drafts for revision }\end{array}$ \\
\hline & $\begin{array}{l}\text { the decided topic } \\
\text { Creating the project } \\
\text { - Asking the students to write an } \\
\text { opinion essay on their blogs, } \\
\text { give peer-feedback and their } \\
\text { work need to be corrected } \\
\text { based on the given feedback }\end{array}$ & $\begin{array}{l}\text { Editing } \\
\text { - Asking the students to do } \\
\text { a final revision }\end{array}$ \\
\hline 5 & $\begin{array}{l}\text { Presenting and evaluating the } \\
\text { project } \\
\text { - Asking the students to present } \\
\text { the result of their writing } \\
\text { through blogging and giving } \\
\text { feedback to their friends' } \\
\text { presentation }\end{array}$ & $\begin{array}{l}\text { Publishing } \\
\text { - Publishing the final result } \\
\text { by showing the results of } \\
\text { their work to classmates }\end{array}$ \\
\hline 6 & $\begin{array}{l}\text { Deciding a topic and designing a } \\
\text { plan for the second project } \\
\text { - Giving the students a topic for } \\
\text { the opinion essay: "Digital }\end{array}$ & $\begin{array}{l}\text { Planning and Drafting } \\
\text { - Giving the students a } \\
\text { topic for the second } \\
\text { opinion essay: “Digital }\end{array}$ \\
\hline
\end{tabular}




\begin{tabular}{|c|c|c|}
\hline & $\begin{array}{l}\text { Literacy" } \\
\text { - Asking the students to work } \\
\text { with the same group, discuss } \\
\text { the topic, blog and its template, } \\
\text { and make an outline }\end{array}$ & $\begin{array}{l}\text { Literacy" } \\
\text { - Asking the students to } \\
\text { brainstorm ideas, make an } \\
\text { outline, and write a rough } \\
\text { draft to be submitted for } \\
\text { feedback from classmates }\end{array}$ \\
\hline 7 & $\begin{array}{l}\text { Collecting the data for the project } \\
\text { - Working in groups and collect } \\
\text { data for the decided topic }\end{array}$ & $\begin{array}{l}\text { Revising } \\
\text { - Returning the students' } \\
\text { work to be revised }\end{array}$ \\
\hline & $\begin{array}{l}\text { Creating the project } \\
\text { - Asking the students to write the } \\
\text { opinion essay on their blogs, to } \\
\text { do peer-feedback and their } \\
\text { work need to be corrected } \\
\text { based on the given feedback }\end{array}$ & $\begin{array}{l}\text { Editing } \\
\text { - Asking the students to do } \\
\text { a final revision }\end{array}$ \\
\hline 8 & $\begin{array}{l}\text { Presenting and evaluating the } \\
\text { project } \\
\text { - Asking the students to present } \\
\text { their essay through blogging } \\
\text { and asking each group to give } \\
\text { feedback to their friends' } \\
\text { presentation }\end{array}$ & $\begin{array}{l}\text { Publishing } \\
\text { - Publishing the final result } \\
\text { by showing the result of } \\
\text { their work to other friends }\end{array}$ \\
\hline 9 & Administering the posttest & Administering the posttest \\
\hline
\end{tabular}

Writing scores of the students and their self-efficacy levels were the main data that need to be obtained. Writing prompts and scoring rubrics were used to elicit the writing scores. An analytical scoring rubric was used by two raters as a guideline to mark the students' essays. The rubric was adapted from Jacob, Zingraf, Wormuth, Hartfield, and Hughey (1981). A questionnaire of selfefficacy was employed to know the self-efficacy levels of subjects (Jacobs et al., 1981). The questionnaire consisted of 15 items which were constructed following Bandura's (2006) recommendation in that the items start with the phrase "I can" to reflect the subjects' capability (Bandura, 2006). The results of the questionnaire are attached in Appendix 1. All of the instruments were validated before being used. The validator of the instruments was an English lecturer of the same university who had expertise in the area of EFL writing.

Before giving the treatment, the pretest was administered and the scores were used to see whether it had a normal distribution and equal ability or not. Since the result of the pretest scores indicated that the scores of both groups had a normal distribution and equal ability, independent sample $t$-test was 
employed to compare the means of the posttest scores of the two groups. In Appendix 2, the scores of pretest and posttest are attached. After administering the posttest, the self-efficacy questionnaire was given to the students to find out the level of their self-efficacy.

The main data of this study was students' scores in writing. It was collected through writing test; pre-test and post-test. In writing prompt tests for the pre-test and post-test, the students were assigned to write an opinion essay based on the topic given by the researcher. Before giving the treatment, the pretest was distributed to the students. The pretest scores obtained were analyzed in order the fulfill the statistical assumptions. The self-efficacy questionnaire then was distributed to the students in the experimental group before the posttest and it was analyzed using Pearson Product Moment Correlation and Cronbach Alpha Coefficient. After that, the posttest was administered to the students. The obtained scores of the post-test were analyzed using independent sample t-test.

\section{RESULTS}

The findings are divided into three parts. The first part deals with the fulfillment of the assumptions. The second part discusses the analysis result of the effect of PjBL through blogging on the students' ability in writing. Last but not least, the last part shows the result of the comparison of the writing ability of the students across self-efficacy levels.

\section{Fulfillment of Assumptions of Normality and Homogeneity}

Before analyzing the data using Independent sample t-test, the data should fulfill two assumptions: assumptions of normality and homogeneity. The Shapiro-Wilk test result for normality shows that the data had a normal distribution as indicated by the significance level of more than 0.05. Additionally, homogeneity test conducted using Levene's test shows that the subjects were homogeneous as shown in the significance level of 0.79 , which is more than 0.05, meaning that the students had an equal ability in writing. Furthermore, independent sample $t$-test was utilized to compare the pretest scores of the two groups to find out whether or not the two groups were significantly different. The result revealed that the two groups had no significant difference since the $p$-value was 0.37 , meaning that it was higher than the 0.05 level of significance. 


\section{The Effect of PjBL on the Students' Writing Ability}

The students' pretest scores of the two groups were equated to find out how PjBL through blogging affected the students' ability in writing. Table 2 displays the result of the posttest scores of the two groups in the form of descriptive statistics.

Table 2. The Descriptive Statistics of the Posttest Scores

\begin{tabular}{llcccc}
\hline & Group & $\mathrm{N}$ & Mean & $\begin{array}{c}\text { Std. } \\
\text { Deviation }\end{array}$ & Std. Error Mean \\
\hline Post.test & Experimental & 19 & 79.1579 & 7.03375 & 1.61365 \\
& Control & 22 & 68.5909 & 6.91898 & 1.47513 \\
\hline
\end{tabular}

Table 2 showed that 79.16 was the mean of the experimental group. In contrast, 68.59 was the mean obtained by the opposite group. Meanwhile, the standard deviation scores of the two groups were 7.03 and 6.91, respectively. To see the comparison of the means of both groups in details, the result can be observed in Table 3.

Table 3. The Result of Comparison of Means of the Experimental and Control Groups

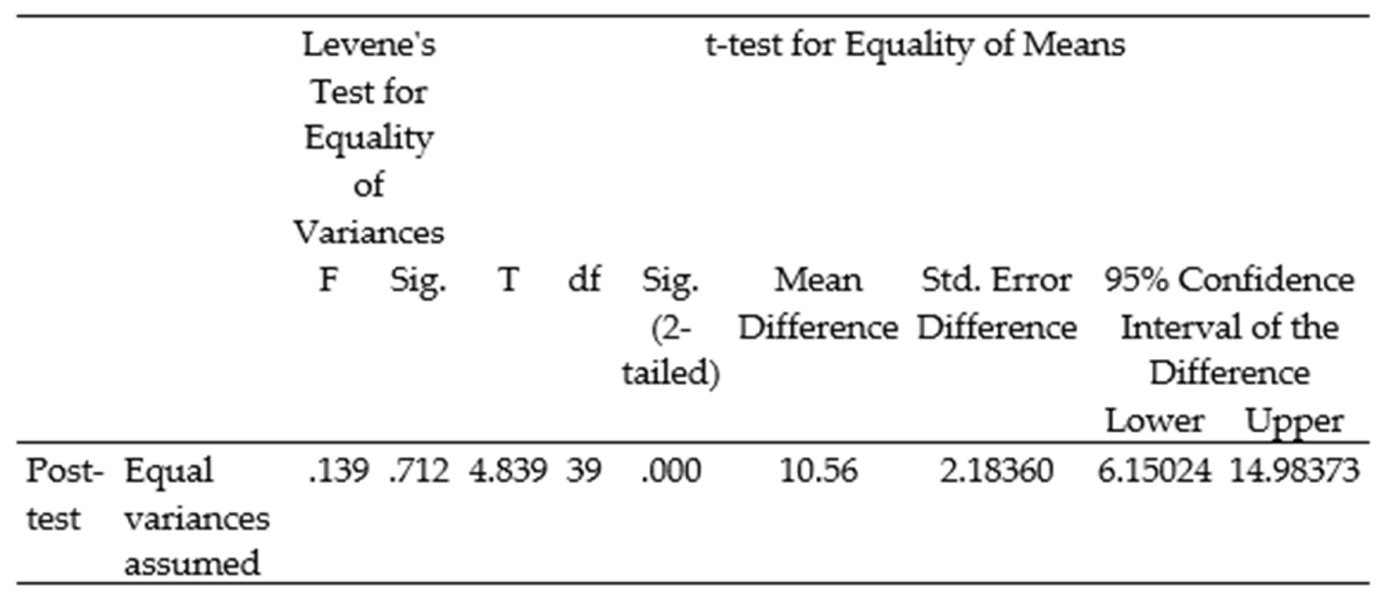

Table 3 demonstrates that the significant value ( $p$-value) was 0.00 indicating that it was under the level of significance set (0.05). Thus, the difference is significant to reject the $\mathrm{H}_{0}$. It is inferred that the students taught using PjBL through blogging achieved better scores in writing than those taught using the conventional method.

Journal on English as a Foreign Language, 9(2), 199-216

Copyright @ 2019 by JEFL, p-ISSN 2088-1657; e-ISSN 2502-6615 


\section{Comparison of Writing Ability across Self-efficacy Levels}

A significant difference in writing ability of the sub-groups; students with low and high self-efficacy taught using PjBL could be found by contrasting means of posttest scores. Table 4 displays the result of the comparison.

Table 4. The Comparison of Means of the Self-efficacy Groups in the Experimental Group

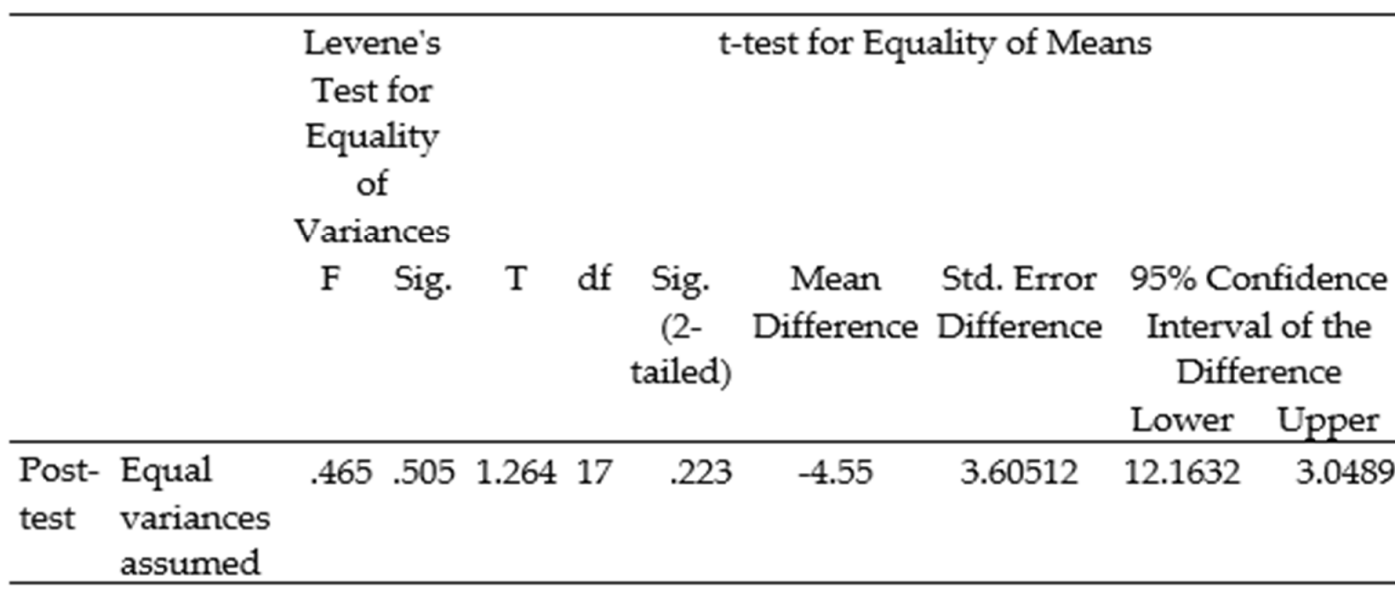

Table 4 displays that the significant value was .223 and it was higher than the 0.05 significance level. Consequently, Ho was accepted. In other words, the writing ability of the two groups of students across self-efficacy levels was not significantly different. Thus, there was no significant difference between students who possessed high self-efficacy and the ones who had low selfefficacy in writing ability taught by using PjBL through blogging.

\section{DISCUSSION}

The result of this study is relevant to the ideas that $\mathrm{PjBL}$ is beneficial and more efficacious than the traditional method (Thomas, 2000). In this study, the PjBL helps the students to be more active during writing activities since the students have control over their projects. Blumenfeld et al. (1991) stated that PjBL enthralls students' involvement and encourages their engagement by offering various topic of real-life projects. Besides, PjBL can spark off students' higher-order cognitive skills, extending towards the betterment of proficiency in their writing skills (Larmer, Mergendoller, \& Boss, 2015). In writing classes, $\mathrm{PjBL}$ made writing activities embedded in a natural setting. It helped the students create levels of language cognition such as topic organization, 
linguistics feature awareness, vocabulary and word choice, and sentence formation (Foulger \& Jimenez-Silva, 2007).

Unfortunately, most of the students still depend on the textbook. As the consequences, sometimes they feel bored during the writing activities. Besides, they tend to have low creativity and enthusiasm to participate in teaching and learning activities since they only do writing tasks based on the textbook on a piece of paper and submit them to their teachers (Astawa et al., 2017). Additionally, the use of PjBL can develop students' writing ability, boost their creativity and enthusiasm since it provides an opportunity to create a productive enjoyable classroom atmosphere through the integration of students' knowledge, and skills (Eskrootchi \& Oskrochi, 2010; Papanikolaou \& Boubouka, 2010).

In the present study, before being exposed to the treatment of $\mathrm{PjBL}$ through blogging, the students often found difficulties such as stating the thesis statement, generating and linking idea, and developing the supporting details since they have no idea what they want to write. Besides, at the beginning of the project, the students still had no idea about how they will do their project (i.e., writing an essay on their blogs) since they never had experience in creating a blog. They tended to write mostly on a piece of paper and then print it out. Nevertheless, those difficulties were then gradually overcome as the treatment of $\mathrm{PjBL}$ through blogging exposed the students to many opportunities to practice more in writing and to focus more on the content. During the treatment, the students worked in groups by discussing, investigating, and exploring possible resources to design and organize ideas and they end up presenting the final project. Furthermore, the students can get feedback from their friends or other bloggers for the betterment of their writing by leaving some comments on the blogs.

Blogs were held as a means of building up students' writing ability (Zhang, 2009; Fageeh, 2011). Besides, applying blog as the students' projectbased technology signified real assistance in generating the students' novel ideas, about their existing knowledge, exploring creativity and expressing their writing skill in the form of an interesting multimedia product. The collaborative work in groups to create a blog in $\mathrm{PjBL}$ enabled the students to be in a conducive learning environment in which they devote time, energy, and effort to create a finished product.

After interpreting and incorporating the data analysis and the hypothesis, we concluded that there was consistency between the findings and 
the existing body of knowledge and former studies dealing with the use of PjBL through blogging on students' writing ability. In this study, combining PjBL with blogging made the students interested in doing the projects since they asked to do the projects collaboratively that they help each other in completing the projects. Furthermore, it was claimed that applying the six stages of PjBL through blogging affected the students' writing ability and those stages contributed to the improvement of their writing ability. Additionally, it is also indicated that the students' ability in writing ability of both groups had a significant difference. Thus, the ones taught by using PjBL through blogging performed better in writing than those taught by using the conventional way.

Students' ability in writing taught by PjBL through blogging was not affected by students' self-efficacy level. This is different from the ideas that it is self-efficacy that becomes a key factor in students' competence, cognition, action, and behaviors (Bandura, 1997; Pintrich, 1999; Pintrich \& de Groot, 1990; Usher \& Pajares, 2008). It is commonly assumed that higher, but reachable goals were owned by students possessing high self-efficacy (Prat-Sala \& Redford, 2012). Besides, when students find challenging situations, their metacognitive schemes will be applied (Linnenbrink \& Pintrich, 2003). In contrast, the ones having low self-efficacy either put a little effort into a challenging assignment (Bandura, 1997). Nevertheless, this study reported the opposite result which somehow students with high or low self-efficacy could equally accomplish better in their writing ability.

The result of the study could be reflected as opposition to what resulted in some studies. The result of the studies revealed that students' ability possessing high self-efficacy gained better scores in writing than those having the opposite one (Kurniawati, 2014; Chea \& Shumow, 2015). They also reported that it was interesting for students having high self-efficacy to do writing task and they also took the tasks as a challenging task that requires to be solved. On the other hand, it is found that low self-efficacy students obtained lower scores compared to those who have high self-efficacy because they do not put so many efforts and solved their difficulties (Meitikasari, 2016). Hence, they cannot compose appropriate sentences. The higher self-efficacy level the students have, the more they can solve their difficulties.

Concerning self-efficacy found in the present study, it is line with studies done by Magogwe, Ramoroka, and Mogana-Monyepi (2015) and Hashemnejad, Zoghi and Amini (2014) who reported similar findings. The results of their studies revealed students' ability in writing and their self-efficacy are not 
connected. They assumed that self-efficacy alone was not sufficient to determine students' writing ability (Hashemnejad, Zoghi, \& Amini, 2014; Magogwe, Ramoroka, \& Mogana-Monyepi, 2015). In other words, self-efficacy did not guarantee that students would be successful in performing a writing task. Other studies supporting the finding of this study are those conducted by Shell, Murphy, and Bruning (1989) and Pajares and Johnson (1994). The results of their studies revealed that self-efficacy cannot predict the students' actual writing ability in composing. It is mentioned by Öztürk and Saydam (2014), not only can self-efficacy predict the students' writing ability, but there is a contribution of anxiety that affects their' writing ability.

In short, although the aforementioned previous studies were still debatable, the result of this present study was implied to support the research which revealed that both low and high self-efficacy owned by the students did not contribute to the students' writing ability.

\section{CONCLUSION}

By contemplating the aforementioned results, the treatment of $\mathrm{PjBL}$ through blogging contributed to the students' writing ability as those applying PjBL achieved better scores in writing than those in the opposite group. All stages of PjBL were proven effective to facilitate students in increasing their writing ability. Also, it is concluded that students possessing high self-efficacy and low self-efficacy taught by using PjBL through blogging had no relationship. All the students had equal opportunity to achieve better in writing since there was no evidence that their self-efficacy affected their writing ability. Therefore, in the application of PjBL through blogging, teachers should not worry about the level of self-efficacy. Theoretically, this experimental study is beneficial since it verifies a theory that $\mathrm{PjBL}$ is effective for writing. Besides, this study has also practical significance for teachers and future researchers. The result of this study enables the English teachers to design more interesting and interactive classroom activities in teaching writing by using $\mathrm{PjBL}$ combined with an online platform, particularly blogging. The last, it will provide additional insights for future researchers into the practice of using PjBL through blogging by using other personality factors.

\section{REFERENCES}

Ariyanti, A. (2016). The teaching of EFL writing in Indonesia. DINAMIKA ILMU, 16(2), 2442-9651. https://doi.org/10.21093/di.v16i2.274

Journal on English as a Foreign Language, 9(2), 199-216

Copyright @ 2019 by JEFL, p-ISSN 2088-1657; e-ISSN 2502-6615 
Astawa, N. L. P. N. S. P., Artini, L. P., \& Nitiasih, P. K. (2017). Project-based learning activities and EFL students' productive skills in English. Journal of Language Teaching and Research, 8(6), 1147-1155. https://doi.org/10.17507 /1tr.0806.16

Bandura, A. (1997). Self-efficacy: The exercise of control. New York: W H Freeman/Times Books/Henry Holt \& Co.

Bandura, A. (2006). Guide to the construction of self-efficacy scales. In F. Pajares \& T. Urdan (Eds.). Self-efficacy beliefs of adolescents (pp. 307-337). Greenwich, CT: IAP - Information Age Publishing. Retrieved from https:/Www.uky.edu/...Bandura/BanduraGuide2006.pdf.

Beckett, G. H., \& Miller, P. C. (2006). Project-based second and foreign language education: Past, present, and future. Retrieved from https:/Arove.nla.gov.au/version/24954527

Blumenfeld, P. C., Soloway, E., Marx, R. W., Krajcik, J. S., Guzdial, M., \& Palincsar, A. (1991). Motivating project-based learning: Sustaining the doing, supporting the learning. Educational Psychologist, 26(3), 369-398. https://doi.org/10.1080/00461520.1991.9653139

Cahyono, B. Y., \& Widiati, U. (2006). The teaching of EFL writing in the Indonesian context: The state of the art. Jurnal Ilmu Pendidikan, 13 (3), 139150.

Campbell, A. P. (2003). Weblogs for use with ESL classes. The Internet TESL Journal, 9(2). Retrieved from http://iteslj.org/Techniques/CampbellWeblogs.html

Chea, S., \& Shumow, L. (2015). The relationships among writing self-efficacy, writing goal orientation, and writing achievement. Language Education in Asia, $5(2)$,

253-269.

https://doi.org/10.5746/LiA/14/N5/2/A07/Chea_Shumow

Cortazzi, M., \& Jin, L. (1996). English teaching and learning in China. Language Teaching, 29(2), 61-80. https://doi.org/10.1017/50261444800008351

Eskrootchi, R., \& Oskrochi, G. R. (2010). A study of the efficacy of project-based learning integrated with computer-basedd simulation - Stella. Educational Technology \& Society, 13(1), 236-245

Fageeh, A. I. (2011). EFL learners' use of blogging for developing writing skills and enhancing attitudes towards English learning: an exploratory study. Journal of Language and Literature, 2(1), 31-48.

Foulger, T. S., \& Jimenez-Silva, M. (2007). Enhancing the writing development of English language learners: teacher perceptions of common technology in project-based learning. Journal of Research in Childhood Education, 22(2), 109-124. https://doi.org/10.1080/02568540709594616 
Goodman, B. (2010). Project-based learning: A dynamic approach to teaching in which students explore real-world problems and challenges, simultaneously developing 21st Century skills while working in small collaborative groups. Retrieved 15 October 2018, from https://www.fsmilitary.org/pdf_Project_Based_Learning.pdf.

Hashemnejad, F., Zoghi, M., \& Amini, D. (2014b). The relationship between selfefficacy and writing performance across genders. Theory and Practice in Language Studies, 4(5), 1045-1052. https://doi.org/10.4304/tpls.4.5.10451052

Jacobs, H. L., Zingraf, S. A., Wormuth, D. R., Hartfield, V. F., \& Hughey, J. B. (1981). Testing ESL composition: A practical approach. Rowley, Mass.: Newbury House Publishers.

Kurniawati, N. (2014). EFL students' writing self-efficacy and its' reflection in their writing performance. JEOPALT Journal, 2(2), 1-14.

Larmer, J., Mergendoller, J., \& Boss, S. (2015). Setting the standard for project-based learning: A proven approach to rigorous classroom instruction. Alexandria, VA: ASCD.

Latief, M. A. (2012). Research methods on language learning: An introduction. Malang: State University of Malang Publisher.

Linnenbrink, E. A., \& Pintrich, P. R. (2003). The role of self-efficacy beliefs in student engagement and learning in the classroom. Reading $\mathcal{E}$ Writing Quarterly: Overcoming Learning Difficulties, 19(2), 119-137. https://doi.org/10.1080/10573560308223

Markham, T., Larmer, J., \& Ravitz, J. (2003). Project-based learning handbook: A guide to standards focused on project-based learning for middle and high school teachers. Novato, CA: Buck Institute for Education.

Magogwe, J. M., Ramoroka, B. T., \& Mogana-Monyepi, R. (2015). Developing student-writers' self-efficacy beliefs. Journal of Academic Writing, 5 (2), 2028. https://doi.org/10.18552 joaw.v5i2.132

Meitikasari, A. (2016). Experiential learning (El): an effective teaching method to construct students' writing skill viewed from self-efficacy. ICTTE, 1(1), 1015-1022.

Öztürk, G., \& Saydam, D. (2014). Anxiety and self-efficacy in foreign language writing: the case in Turkey Yabanc1. Baskent University Journal of Education, 1(2), 10-21.

Pajares, F., \& Johnson, M. J. (1994). Confidence and competence in writing: the role of self-efficacy, outcome expectancy, and apprehension. Research in the Teaching of English, 28, 313-331.

Journal on English as a Foreign Language, 9(2), 199-216

Copyright (C) 2019 by JEFL, p-ISSN 2088-1657; e-ISSN 2502-6615 
Papanikolaou, K., \& Boubouka, M. (2010). Promoting collaboration in a projectbased e-learning context. Journal of Research on Technology in Education, 43(2), 135-155. https://doi.org/10.1080/15391523.2010.10782566

Pintrich, P. R. (1999). The role of motivation in promoting and sustaining selfregulated learning. International Journal of Educational Research, 31(6), 459470. https://doi.org/10.1016/50883-0355(99)00015-4

Pintrich, P. R., \& de Groot, E. V. (1990). Motivational and self-regulated learning components of classroom academic performance. Journal of Educational Psychology, 82(1), 33-40. https://doi.org/10.1037 0022-0663.82.1.33

Prat-Sala, M., \& Redford, P. (2012). Writing essays: Does self-efficacy matter? The relationship between self-efficacy in reading and in writing and undergraduate students' performance in essay writing. Educational Psychology, 32(1), 9-20. https://doi.org/10.1080/01443410.2011.621411

Richards, J. C., \& Renandya, W. A. (2002). Methodology in language teaching: An anthology of current practice. Cambridge: Cambridge University Press.

Sadeghi, H., Biniaz, M., \& Soleimani, H. (2016). The impact of project-based language learning on Iranian EFL learners comparison/contrast paragraph writing skills. International Journal of Asian Social Science, 6(9), 510-524. https://doi.org/10.18488 łournal.1/2016.6.9/1.9.510.524

Shell, D., Murphy, C., \& Bruning, R. (1989). Self-efficacy and outcome expectancy mechanisms in reading and writing achievement. Journal of Educational Psychology, 81, 91-100.

Stoller, F. (2006). Establishing a theoretical foundation for project-based learning in second and foreign language contexts. In G. H. Beckett, \& P. C. Miller, Eds., Project-Based Second and Foreign Language Education: Past, Present, and Future (pp. 19-40). Greenwich, CT: Information Age.

Thitivesa, D., \& Essien, A. M. (2013). The use of project to enhance writing skill. International Journal of Educational and Pedagogical Sciences, 7(6), 1568-1572.

Thomas, J. W. (2000). A review of research on project-based learning. San Rafael, California: The Autodesk Foundation.

Usher, E. L., \& Pajares, F. (2008). Sources of self-efficacy in School: Critical review of the literature and future directions. Review of Educational Research, 78(4), 751-796. https://doi.org/10.3102/0034654308321456

Zhang, D. (2009). The application of blog in English writing. Journal of Cambridge Studies, 4(1), 62-72. 


\section{Authors' Brief CV}

Ikrima Halimatus Sa'diyah finished her Undergraduate Program from Jember University, East Java, Indonesia, in 2016 majoring in ELT. She is now taking the Graduate Program in the same major at Universitas Negeri Malang.

Bambang Yudi Cahyono is a Professor in Applied Linguistics at Universitas Negeri Malang, East Java, Indonesia. He earned his M.A. from Concordia University, Montreal, Canada and Ph.D. from the University of Melbourne, Australia.

\section{Appendix 1: The results of self-efficacy questionnaire}

\begin{tabular}{|c|c|c|}
\hline Students & Scores & Level \\
\hline 1 & 43 & high \\
\hline 2 & 51 & high \\
\hline 3 & 50 & high \\
\hline 4 & 43 & high \\
\hline 5 & 35 & low \\
\hline 6 & 37 & low \\
\hline 7 & 42 & high \\
\hline 8 & 37 & high \\
\hline 9 & 49 & high \\
\hline 10 & 52 & high \\
\hline 11 & 51 & high \\
\hline 12 & 45 & high \\
\hline 13 & 48 & high \\
\hline 14 & 37 & low \\
\hline 15 & 37 & low \\
\hline 16 & 45 & high \\
\hline 17 & 43 & high \\
\hline 18 & 36 & low \\
\hline 19 & 35 & high \\
\hline
\end{tabular}


Appendix 2: Pre-test and post-test scores

\begin{tabular}{|c|c|c|c|c|c|}
\hline \multicolumn{3}{|c|}{ Experimental group } & \multicolumn{3}{c|}{ Control group } \\
\hline Students & Pre-test & Post-test & Students & Pre-test & Post-test \\
\hline 1 & 61 & 66 & 1 & 80 & 82 \\
\hline 2 & 65 & 84 & 2 & 68 & 70 \\
\hline 3 & 70 & 85 & 3 & 63 & 70 \\
\hline 4 & 71 & 82 & 4 & 62 & 65 \\
\hline 5 & 70 & 75 & 5 & 56 & 65 \\
\hline 6 & 69 & 81 & 6 & 59 & 60 \\
\hline 7 & 83 & 88 & 7 & 58 & 60 \\
\hline 8 & 70 & 75 & 8 & 59 & 60 \\
\hline 9 & 70 & 77 & 9 & 59 & 60 \\
\hline 10 & 81 & 88 & 10 & 70 & 73 \\
\hline 11 & 75 & 77 & 11 & 60 & 65 \\
\hline 12 & 60 & 79 & 12 & 69 & 70 \\
\hline 13 & 64 & 75 & 13 & 67 & 70 \\
\hline 14 & 58 & 61 & 14 & 63 & 65 \\
\hline 15 & 70 & 76 & 15 & 62 & 65 \\
\hline 16 & 80 & 83 & 16 & 60 & 65 \\
\hline 17 & 62 & 83 & 17 & 55 & 60 \\
\hline 18 & 75 & 86 & 18 & 66 & 80 \\
\hline 19 & 72 & 83 & 19 & 74 & 77 \\
\hline- & - & - & 20 & 73 & 76 \\
\hline- & - & - & 21 & 72 & 76 \\
\hline- & - & - & 22 & 70 & 75 \\
\hline & & & & & \\
\hline
\end{tabular}

Journal on English as a Foreign Language, 9(2), 199-216

Copyright @ 2019 by JEFL, p-ISSN 2088-1657; e-ISSN 2502-6615 